\title{
UJI DAYA HAMBAT EKSTRAK ETANOL SURUHAN (Piperumia pellucida L.H.B Kunth) TERHADAP PERTUMBUHAN BAKTERI Staphylococcus aureus SECARA IN-VITRO
}

\author{
Eldo Dandirwalu ${ }^{1}$ dan Theopilus W. Watuguly ${ }^{2}$ \\ ${ }^{1}$ Alumni Program Studi Pendidikan Biologi \\ ${ }^{2}$ Dosen Program Studi Pendidikan Biologi
}

E-mail: theo_watuguly@yahoo.com

\begin{abstract}
Background: Staphyloccocus aureus represent normal mikroflora of human being. This bacterium usually there are at bronchi to the and husk. Existence of Staphyloccocus aurues at bronchi to the and husk at individual seldom cause disease, healthy individual usually only personating career. One of the original plant that is plant of suruhan (Piperumia pellucida L.H.B. Kunth) biggest and wide of in some area in Indonesia (Molluca) and also have potency to be developed as traditional drug, empirically have been used in medication of abscess (abses) by society.

Methods: This Research use eksperimental in Laboratory with research device is Complete Random Device (Factorial RAL) Pattern from two factor and 3 restating, which in doing/conducting in Elementary Laboratory of Biology Faculty Teachership and Science Education of Pattimura University.

Resulth: Result research of to extract etanol plant suruhan (Piperumia pelludica L.H.B Kunth) to growth of bacterium of Staphylococcus aureus with various concentration that is $25 \%, 50 \%$ and $75 \%$ and there is influence contact to growth of bacterium where at concentration $25 \%$ is equal to $5 \mathrm{~mm}$ donot give respon pursue, $50 \%$ is equal to $10 \mathrm{~mm}$ with weak resistance respon and $75 \%$ is equal to 16 with resistance respon.

Conclusion: Extract concentration excelsior of etanol plant of suruhan (Piperumia pelludica L.H.B Kunth) and old progressively of contact with bacterium of Staphylococcus aureus hence resistivity progressively goodness.
\end{abstract}

Keyword: Test Resistivity, Extract Etanol Plant Suruhan (Piperumia pelludica L.H.B Kunth), Bacterium Staphylococcus aureus.

\begin{abstract}
Abstrak
Latar Belakang: Staphyloccocus aurues merupakan mikroflora normal manusia. Bakteri ini biasanya terdapat pada saluran pernapasan atas dan kulit. Keberadaan Staphyloccocus aurues pada saluran pernapasan atas dan kulit pada individu jarang menyebabkan penyakit, individu sehat biasanya hanya berperan sebagai karier. Salah satu tumbuhan asli yaitu tumbuhan suruhan (Piperumia pellucida L.H.B. Kunth) yang tersebarluas di beberapa daerah di Indonesia (Maluku) serta berpotensi untuk dikembangkan sebagai obat tradisional, secara empiris telah digunakan dalam pengobatan bisul (abses) oleh masyarakat.

Metode: Penelitian ini merupakan penelitian eksperimental di Laboratorium dengan rancangan penelitian adalah Rancangan Acak Lengkap (RAL) Pola Faktorial dari dua faktor dan 3 ulangan, yang dilakukan di Laboratorium Dasar Biologi Fakultas Keguruan dan IImu Pendidikan Universitas Pattimura. Hasil: Hasil penelitian menunjukan bahwa ekstrak etanol tumbuhan suruhan (Piperumia pelludica L.H.B Kunth) terhadap pertumbuhan bakteri Staphylococcus aureus dengan berbagai konsentrasi yaitu $25 \%$, $50 \%$ dan $75 \%$ dan terdapat pengaruh kontak terhadap pertumbuhan bakteri dimana pada konsentrasi $25 \%$ adalahs ebesar $5 \mathrm{~mm}$ tidak memberikan respon hambat, $50 \%$ adalah sebesar $10 \mathrm{~mm}$ dengan respon hambatan lemahdan $75 \%$ adalah sebesar 16 dengan respon hambatan sedang.

Kesimpulan: semakin tinggi konsentrasi ekstrak etanol tumbuhan suruhan (Piperumia pelludica L.H.B Kunth) dan semakin lama kontak dengan bakteri Staphylococcus aureus maka daya hamba tsemakin baik.
\end{abstract}

Kata Kunci: Uji Daya Hambat, Ekstrak Etanol Tumbuhan Suruhan (Piperumia pelludica L.H.B Kunth), BakteriS taphylococcus aureus. 


\section{PENDAHULUAN}

Staphyloccocus aureus adalah bakteri gram positif yang bersifat anaerob fakultatif, tidak menghasilkan spora dan tidak motil, umumnya tumbuh berpasangan maupun berkelompok, dengan diameter sekitar 0,91,3um. Staphyloccocus aurues merupakan mikroflora normal manusia. Bakteri ini biasanya terdapat pada saluran pernapasan atas dan kulit. Keberadaan Staphyloccocus aurues pada saluran pernapasan atas dan kulit pada individu jarang menyebabkan penyakit, individu sehat biasanya hanya berperan sebagai karier. Infeksi serius akan terjadi ketika resistensi inang melemah karena adanya perubahan hormon, adanya penyakit, luka atau penggunaan steroid atau obat lain yang mempengaruhi imunitas sehingga terjadi pelemahan inang (Jawetz, $d k k, 2005)$.

Adanya kontaminasi mikroba dapat menyebabkan penyakit infeksi. Penyakit infeksi yang disebabkan oleh bakteri salah satunya Staphyloccocus aurues, ini diasiosasikan dengan beberapa kondisi diantarannya bisul, jerawat, pneumonia, meningitis, dan arthritis. Staphyloccocus aurues juga menghasilkan katalase yaitu enzim yang mengkonversi $\mathrm{H}_{2} \mathrm{O}_{2}$ menjadi $\mathrm{H}_{2} \mathrm{Odan} \mathrm{O}_{2}$, dan koagulase, enzim yang menyebabkan fibrin berkoagulasi dan mengumpal. Koagulase diasiosasikan dengan patogenitas karena pengumpulan fibrin yang disebabkan oleh enzim ini terakomulasi di sekitar bakteri sehingga agen pelindung inang kesulitan mencapai bakteri dan fagositosis terhambat (Jawetz, $d k k ., 2005)$.

Mikroba-mikroba secara alami kebal dan bermutasi, selain dapat bertahan hidup dengan antobiotik, mikroba juga dapat menyebabkan penyakit yang lebih serius dan menghasilkan tingkat kematian yang lebih besar. Pemakaian antibiotik yang tidak tepat untuk pengobatan infeksi bakteri dapat memunculkan berbagai masalah setelah puluhan tahun pemakaiannya yaitu dapat menimbulkan resistensi terhadap antibiotika (Green dkk., 2005). Dewasa ini, masyarakat mulai sadar bahwa obat modern yang umumnya berupa zat kimia memiliki kelemahan-kelemahan yang signifikan, pada sisi lain terdapat kelebihan obat herbal (Winarto, 2007). Hal ini didukung adanya penelitian-penelitian terdahulu yang merekomendasikan pengunaan herbal untuk memenuhi berbagai kebutuhan pengobatan terhadap penyakit yang saat ini sedang berkembang (Green, dkk., 2005).

Tumbuhan suruhan (Piperumia pelludica L.H.B Kunth) adalah Salah satu tumbuhan asli Indonesia yang terbesar dengan luas di beberapa daerah di Indonesia (Maluku) memiliki potensi untuk dikembangkan sebagai obat tradisonal. Tumbuhan ini mengandung senyawa kimia golongan glikosida, flavonoid, tannin dan steroid/triterpenoid (Lestari, 2010). Menurut Hembing (2008), bagian yang berkhasiat dari suruhan adalah batang dan daunnya untuk mengatasi nyeri pada rematik, penyaki tasamurat, sakit kepala, sakit perut, abses, bisul, jerawat, radang kulit, luka terpukul dan luka bakar ringan. Beberapa hasil penelitian yang telah dilakukan menunjukkan bahwa tumbuhan suruhan (Piperumia pelludica L.H.B. Kunth) mempunyai potensi sebagai anti inflamasi (Wijaya dan Monica, 2004), anti piretik (Khan, et al., 2007), anti mikroba dan anti kanker (Wei, et al., 2011), dan memiliki efek analgetik (Mulyani, 2011).

\section{METODE}

Penelitian ini merupakan penelitian eksperimental di Laboratorium dengan rancangan penelitian adalah Rancangan Acak Lengkap (RAL) Pola Faktorial dari dua faktor dan 3 ulangan dengan tiga konsentrasi ekstrak antara lain 25\%, 50\%, dan $75 \%$. Sebagai kontrol positif menggunakan tetraksiline dengan konsentrasi $30 \%(\mathrm{~g} / \mathrm{ml})$ dan kontrol negatif menggunakan aquadest steril, yang dilakukan di Laboratorium Dasar Biologi Fakultas Keguruan dan IImu Pendidikan dan Laboratorium Kimia Dasar Fakultas MIPA Universitas Pattimura. Penelitian ini di lakukan selama 3 minggu pada tanggal 31 Maret s/d 21 April 2015.

\section{HASIL DAN PEMBAHASAN}

Setelah dilakukan uji antibakteri ekstrak tumbuhan suruhan selama 24 jam kemudian mengukur dan menghitung rata-rata diameter zona hambat pertumbuhan bakteri Staphylococcus aureus sebagai respon terhadap berbagai konsentrasi ekstrak yang dilihat pada tabel 1 di bawah ini. 
Tabel 1. Rata-rata Diameter Zona Hambat Ekstrak Etanol Tumbuhan Suruhan (Piperumia pelludica L.H.B Kunth) Terhadap Pertumbuhan Bakteri Staphylococcus aureus Secara In-Vitro.

\begin{tabular}{|c|c|c|c|c|c|c|}
\hline \multirow{2}{*}{$\begin{array}{c}\text { Konsentrasi } \\
(\%)\end{array}$} & \multicolumn{3}{|c|}{ Diameter Daerah Hambatan (mm) } & \multirow{2}{*}{$\begin{array}{l}\text { Total } \\
(\mathrm{mm})\end{array}$} & \multirow{2}{*}{$\begin{array}{c}\text { Rata-rata } \\
\text { (mm) }\end{array}$} & \multirow{2}{*}{$\begin{array}{l}\text { Respon } \\
\text { Hambatan }\end{array}$} \\
\hline & U1 & $\mathrm{U} 2$ & U3 & & & \\
\hline 25 & 5 & 5 & 4 & 14 & 5 & Tidak ada \\
\hline 50 & 10 & 10 & 9 & 29 & 10 & Lemah \\
\hline 75 & 16 & 17 & 14 & 47 & 16 & Sedang \\
\hline Kontrol (+) & 21 & 30 & 23 & 74 & 25 & Kuat \\
\hline Kontrol (-) & 0 & 0 & 0 & 0 & 0 & Tidak ada \\
\hline Total & 52 & 62 & 50 & & & \\
\hline
\end{tabular}

$\mathrm{K}-25 \%, \mathrm{~K}-50 \%, \mathrm{~K}-75 \%$, Kontrol; U1 = Ulangan 1, U2 = Ulangan 2, U3 = Ulangan 3.

Berdasarkan tabel 1 di atas menunjukan bahwa, hasil pengukuran diameter zona hambat untuk konsentrasi $25 \%$ adalah sebesar $5 \mathrm{~mm}$ dan tidak memberikan respon hambatan, untuk konsentrasi $50 \%$ adalah sebesar $10 \mathrm{~mm}$ dengan respon hambatan lemah, sedangkan pada konsentrasi $75 \%$ adalah sebesar 16 dengan respon hambatan sedang. Untuk perlakuan kontrol positif dengan pemberian tetraksilin 3\% diperoleh rata-rata diameter zona hambat sebesar 25 $\mathrm{mm}$ dengan respon hambatan kuat, sedangkan untuk kontrol negatif yang diberikan aquades steril tidak memberikan respon hambatan. Hasil zona hambat dapat dilihat pada gambar 1 di bawah ini.

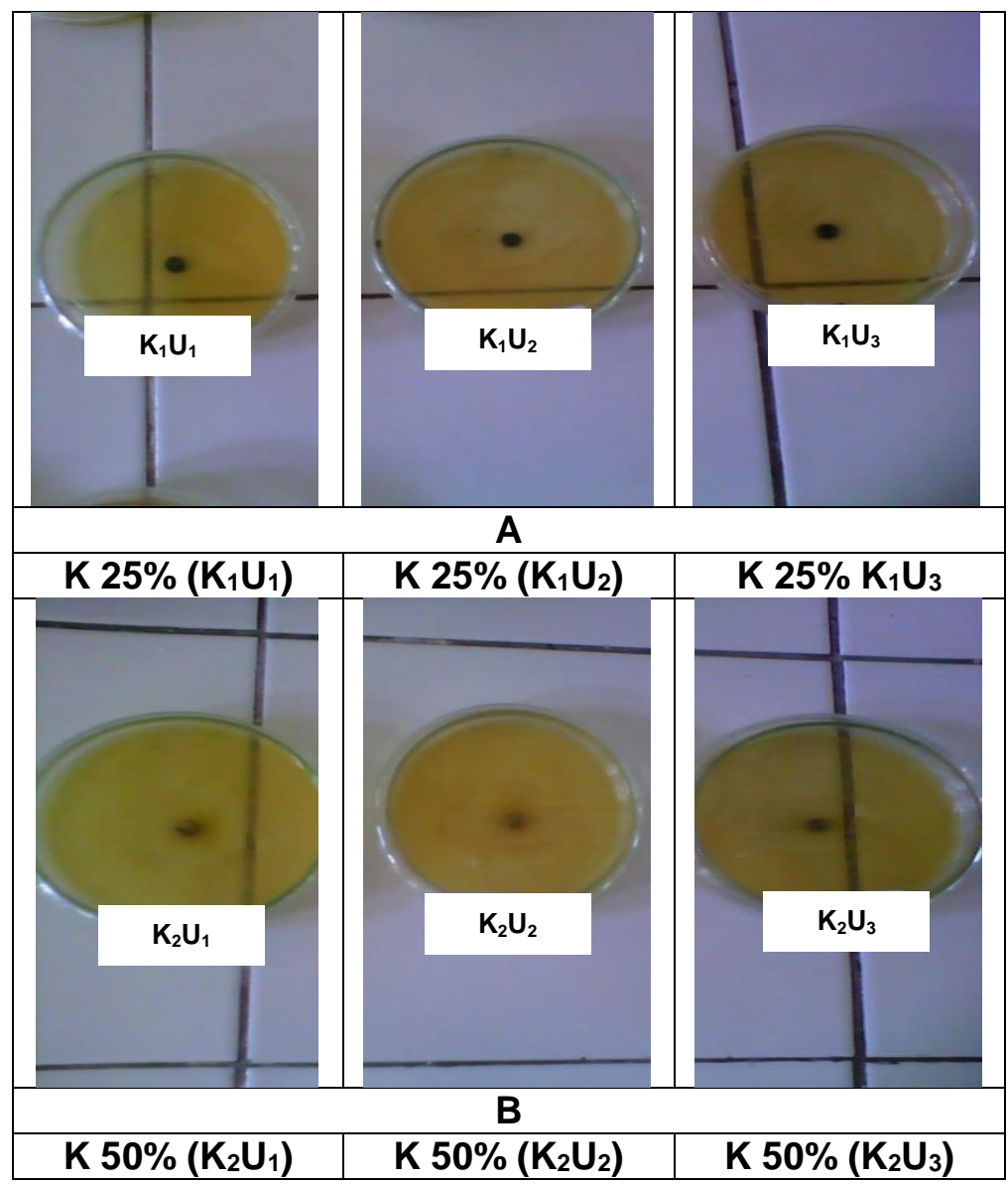




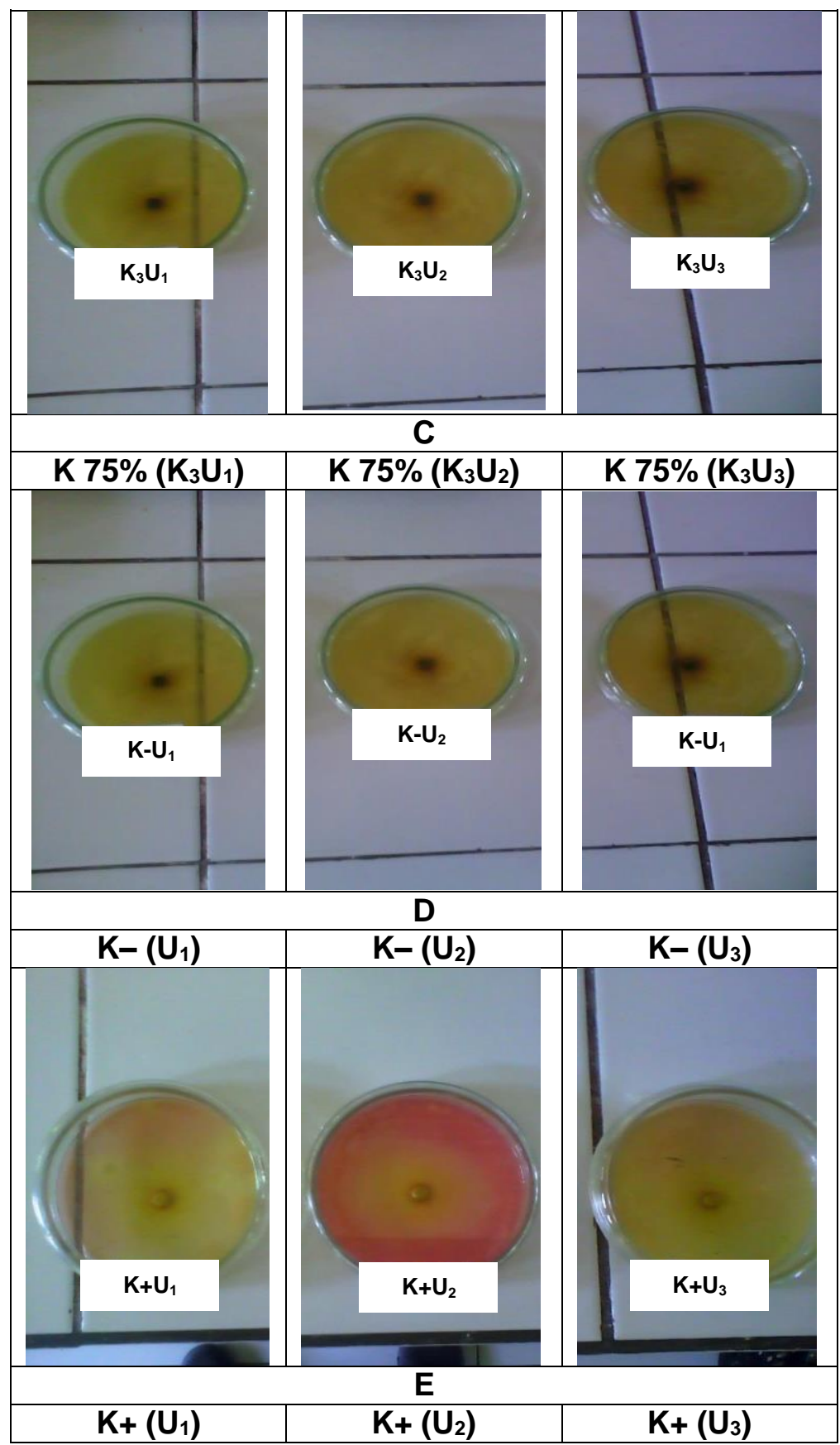

Gambar 1. Zona Hambat Ekstrak Etanol Tumbuhan Suruhan (Piperumia pelludica L.H.B Kunth) Terhadap Pertumbuhan Bakteri Staphylococus aureus Secara In-Vitro: A) K-25\%, B) K-50\%, C) K-75\%, D) Kontrol Negatif (-) dan E) Kontrol Posotif (+). 


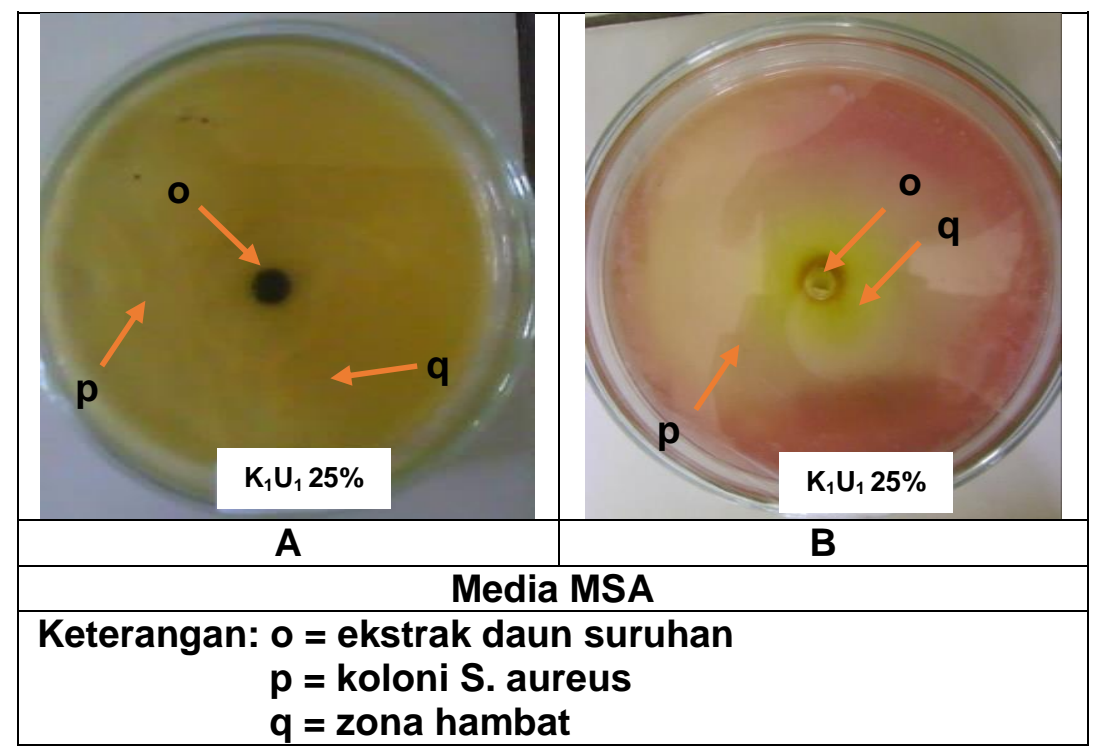

Gambar 2. Zona Hambat Pertumbuhan Bakteri Staphylococcus aureus: K-75\% dan Kontrol Positif (+).

Zona hambat menggambarkan sensitivitas antibakteria ekstrak etanol tumbuhan suruhan (Piperumia pelludica L.H.B Kunth) dalam menghambat pertumbuhan bakteri Staphylococcus aureus.
Data hasil rata-rata pengukuran zona hambatan dari uji antibakteri ekstrak etanol tumbuhan suruhan (Piperumia pelludica L. $\mathrm{H}$. B Kunth) terhadap pertumbuhan bakteri Staphylococcus aureus dapat dilihat pada grafik 3 berikut.

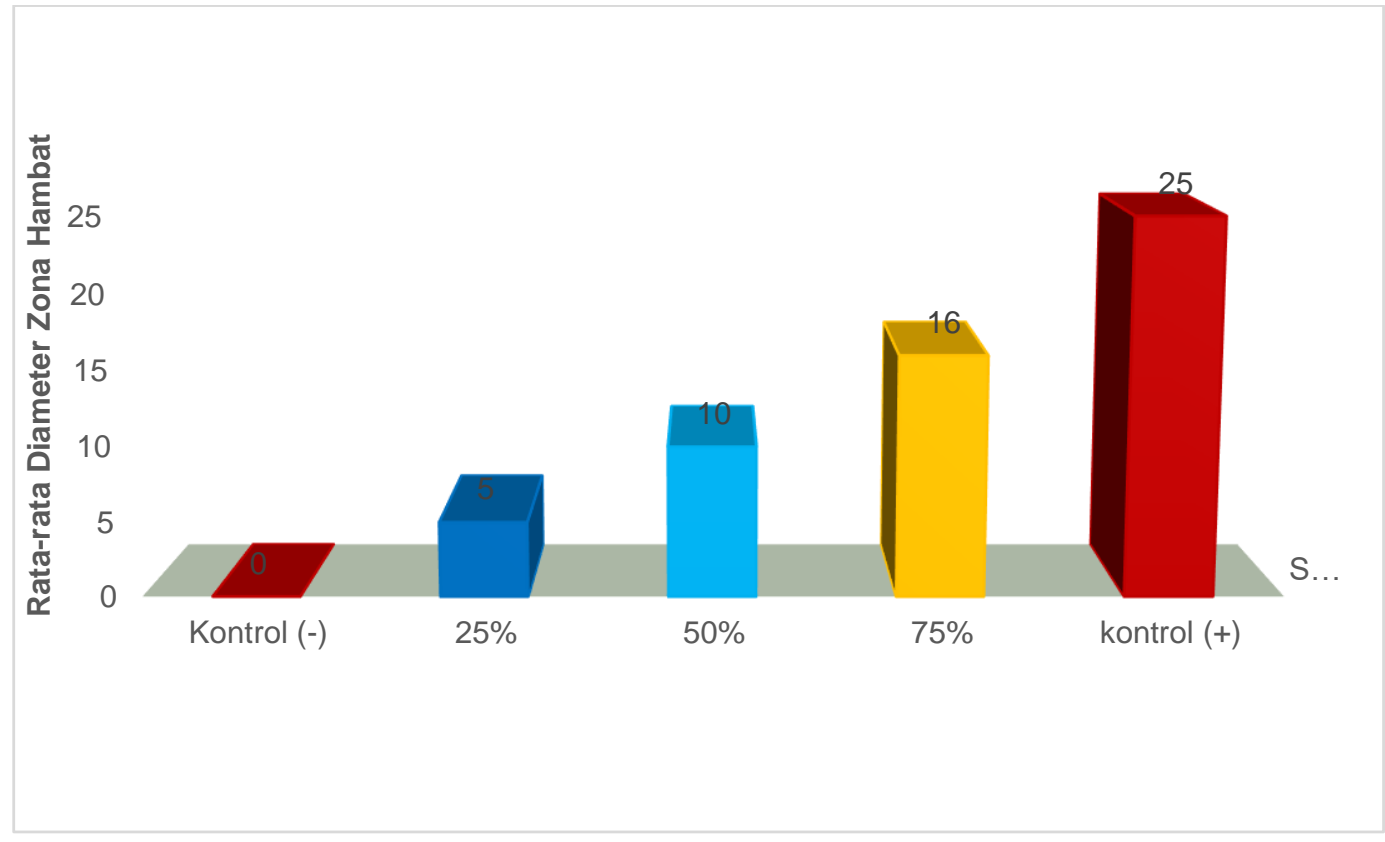

Gambar 3. Grafik rata-rata diameter zona hambat Ekstrak Etanol Tumbuhan Suruhan (Piperumia pelludica L.H.B Kunth) Terhadap Bakteri Staphylococcus aureus.

Berdasarkan hasil uji antibakteri ekstrak etanol tumbuhan suruhan (Piperumia pelludica L.H.B Kunth) terhadap pertumbuhan bakteri Staphylococcus aureus tampak bahwa pemberian ekstrak dengan variasi konsentrasi $25 \% \quad 50 \%$ dan $75 \%$ 
menunjukan adanya respon hambatan dari ekstrak etanol tumbuhan suruhan (Piperumiapelludica L.H.B Kunth) dengan rata-rata diameter zona hambatan 5-16 $\mathrm{mm}$ dengan respon hambatan sedang. Zona hambat terkecil yaitu pada konsentrasi $25 \%$ dan zona hambat terbesar pada konsentrasi $75 \%$. pada konsentrasi $25 \%$ dan zona hambat terbesar pada konsentrasi $75 \%$. Adanya perbedaan tingkat hambatan dari berbagai konsentrasi disebabkan karena semakin tinggi konsentrasi ekstrak etanol tumbuhan suruhan (Piperumiapelludica L.H.B Kunth) maka kandungan bahan aktifnya juga akan semakin besar sehingga luas zona hambatan yang terbentuk juga semakin besar.

Tumbuhan suruhan (Piperumiapelludica L.H.B Kunth) mempunyai spektrum antimikroba yang lebar sehingga dapat membunuh bakteri gram positif dan bakteri gram negatif. Berdasarkan hasil penelitian yang ada, tumbuhan suruhan (Piperumiapelludica L.H.B Kunth) dapat membunuh bakteri flora normal intestinal yang menjadi patogen, tumbuhan suruhan (Piperumiapelludica L.H.B Kunth) juga dapat mengatasi bakteri-bakteri yang telah resisten terhadap antibiotik dan toksin yang dihasilkan oleh bakteri dapat dihambat oleh zat antimikroba tumbuhan suruhan (Piperumiapelludica L.H.B Kunth). Kandungan senyawa aktif dalam tumbuhan suruhan (Piperumiapelludica L.H.B Kunth) yang berperan sebagai zat antibakteri dengan unsur utama allin yang secara enzimatis dipecah oleh enzim allinase menjadi senyawa allisin yang menyebabkan fibrin berkoagulasi dan mengumpal serta menghasilkan, katalase, polifenol, dan flavonoid.

Kandungan lain yang dimiliki tumbuhan suruhan yaitu alisin yang efektif dapat membunuh mikroba, seperti kuman-kuman penyebab infeksi. Alisin menyerang katalisator biologis atau enzim pada bagian bawah atau dalam lapisan bakteri yang digunakan untuk pertumbuhan dan reproduksi. Terdapat juga senyawa Senyawa polifenol mampu merusak membran sel menginaktifkan enzim dan mendenaturasi protein pada bakteri sehingga dinding sel bakteri akan mengalami penurunan permeabilitas yang memungkinkan terganggunya transport ion- ion organik penting yang akan masuk ke sel bakteri. Hal ini mengakibatkan pertumbuhan sel terhambat dan sel mengalami kematian. Oleh karena itu polifenol berperan sebagai senyawa antibakteri (Tamisi, 2008). Kemudian ada juga flavonoid yang merupakan kelompok dari fitokimia fenolik yang berfungsi sebagai peredam radikal bebas yang sangat kuat dan membantu mencegah penyakit yang berhubungan dengan stres oksidatif, serta memiliki aktivitas antimikroba, antikarsinogen, antialergi dan antiinflamasi (Lestari, 2010).

\section{KESIMPULAN}

Berdasarkan pada uraian hasil penelitian dan analisa data yang telah dikemukakan, maka dapat ditarik kesimpulan dari penelitian ini sebagai berikut.

1. Estrak Etanol Tumbuhan Suruhan (Piperumiapelludica L.H.B Kunth) dengan konsentrasi yang berbeda berpengaruh terhadap pertumbuhan bakteri Staphylococcus aureus.

2. Semakin tinggi konsentrasi ekstrak tumbuhan suruhan (Piperumiapelludica L.H.B Kunth) maka semakin tinggi diameter zona hambat pertumbuhan bakteri Staphylococcus aureus yang terdapat pada konsentrasi $75 \%$ dengan zona hambatan $16 \mathrm{~mm}$.

\section{DAFTAR PUSTAKA}

Green James, Rianto S, 2005, Pengobatan alami mengatasi bakteri, Jakarta: Prestasi Pustaka.

Hembing W. 2008. Bebas Diabetes Melitus Ala Hembing. Jakarta: Puspa Swara.

Jawetz, E., G.E. Melnick., C.A. Adelberg. 2005. Mikrobiologi Kedokteran. Buku 2. Diterjemahkan oleh dr. Nani Widorini. Penerbit Salemba Medika. Jakarta.

Khan, A., Ra hman, M., dan Islam, S. 2007. Antipyretic Activity of Peperomia pellucida Leaves in Rabbit. Turk J Biol. 32(1): 37-4.

Lestari, P. 2010). Karakterisasi Simplisia Dan Isolasi Senyawa Triterpenoida/Steroida Dari Herba Suruhan (Peperomiae pellucidae herba). Skripsi. Medan: Fakultas Farmasi Universitas Sumatera Utara. 
Mulyani, D. 2011. Uji Efek Analgetik Herba Suruhan (Peperomia pellucida) Pada Mencit Putih Betina. Scientia. 1(2): 3438.

Tamisi. 2008. Flavonoid dalam Purnomo, M. 2001. Isolasi Flavonoid dari Daun Beluntas (Pluchea indica Less) yang mempunyai Aktivitas Antimikroba.

Wei, S.L., Wee, W., Siong, J.Y.F., dan Syamsumir, D.F. 2011. Characterization of Anticancer, Antimicrobial, Antioxidant Properties and Chemical Compositions of Peperomia pellucida Leaf Extract.

Wijayanti, W. A. 2008. Uji Aktivitas Mukolitik infusa Daun Pare (Momoridica charantia L.) Pada Mukus Usus Sapi secara in Vitro.

Winarto W.P, 2007, Tanaman Obat Indonesia Untuk Pengobatan Herbal. Jilid 3. Jakarta: Karyasari Herba Media. 